\title{
Pollen morphological variation in Vanguerieae (Ixoroideae - Rubiaceae)
}

\author{
FREDERIC LENS, STEVEN JANSEN, SUZY HUYSMANS, ELMAR ROBBRECHT and ERIK SMETS
}

\begin{abstract}
Lens, F., Jansen, S., Huysmans, S., Robbrecht, E. \& Smets, E. 2000. Pollen morphological variation in Vanguerieae (Ixoroideae - Rubiaceae). - Grana 39: 90-102. ISSN 0017-3134.

The Vanguerieae is a large tribe of the subfamily Ixoroideae (Rubiaceae) and consists of about 500 species in 27 genera. This study gives a detailed pollen morphological description of 30 species from 16 genera, based on light microscopy and scanning electron microscopy. The Vanguerieae are considered to be stenopalynous, although there is some evidence to question this. First, there is a difference in sexine types that clearly defines Keetia and Psydrax (both reticulate), and Canthium and Vanguerieae (both perforate with very small perforations) from the other Vanguerieae investigated. Second, pollen grains corroborate the subgeneric delimitations of Canthium sensu Bridson. Pollen morphologically the tribe is characterised by (1) the shape of the ectoapertures which is intermediate between a colpus and a porus, and (2) the presence of a costa oriented perpendicular to the ectoaperture and has a form which is correlated with the shape of the costa.
\end{abstract}

Frederic Lens, Steven Jansen, Suzy Huysmans \& Erik Smets, Laboratory of Plant Systematics, Institute of Botany and Microbiology, K.U.Leuven, Kardinaal Mercierlaan 92, B-3001 Leuven; Elmar Robbrecht, National Botanic Garden of Belgium, Domein van Bouchout, B-1860 Meise; Belgium. E-mail: frederic.lens@bio.kuleuven.ac.be.

(Manuscript accepted 29 September 2000)

With nearly 500 species arranged in 27 genera, the Vanguerieae is one of the larger tribes of the subfamily Ixoroideae (Rubiaceae). It is widespread in tropical Africa, Asia, Australia and the isles of the Pacific Ocean, but the largest number of species occurs in Africa and Madagascar (Bridson 1987a). The habit is generally shrubby, but also few large trees and lianas occur. The tribe combines many distinctive features, e.g. axillary paired inflorescences, valvate aestivation, secondary pollen presentation, one pendulous ovule per locule, pyrenes with an apical germination slit, and seeds with soft oily endosperm and very large embryos (Robbrecht 1988).

According to the classification of Schumann (1891), the Vanguerieae were placed in the supertribe 'Guettardinae' together with the Alberteae, Guettardeae, Retiniphylleae and Knoxieae. This phylogenetic relationship was adopted by Robbrecht $(1988,1994)$ who united these tribes in his subfamily Antirheoideae. Molecular data have demonstrated more recently that the subfamily Antirheoideae is polyphyletic and that the Vanguerieae and the closely related Alberteae belong to the Ixoroideae (Bremer et al. 1995, Andreasen \& Bremer 1996, Bremer 1996, Bremer \& Thulin 1998, Andersson \& Rova 1999, Andreasen et al. 1999, Rova 1999).

Although the Vanguerieae are well characterised morphologically, the generic delimitation remains problematic. Robyns (1928) was the first taxonomist who dealt with this problem. He revised the tribe, without treating Canthium, which is the largest genus that most likely plays a key role in the tribe's phylogeny (Bridson 1992). The high degree of homogeneity within the Vanguerieae is discussed by Verdcourt (1958, 1987:123) who commented on 'the poorness of characters used for generic delimitation'. According to Verdcourt, the strong morphological resem- blances would most probably reduce the number of genera. After the revision of Canthium by Bullock (1932), Bridson (1985, 1986, 1987a $b, 1992)$ refuted the opinion of Verdcourt. She accepted and broadened, on the basis of morphological features, several genera of Canthium s.l., e.g. Psydrax, Pyrostria, Keetia and Multidentia. Furthermore, she recognised four subgenera for the remaining species (= Canthium s.s.), namely Canthium, Afrocanthium, Lycioserissa and Bullockia. These taxonomic changes are also supported by other authors, such as Tilney et al. (1988) who studied anatomical features of young stems of South African species of Canthium s.l.

The macromorphological homogeneity of the tribe becomes also evident in the pollen morphology. Robyns (1928:6) mentioned that pollen grains in the Vanguerieae are 'tres semblables dans tout le groupe'. Verdcourt (1958) came to the same conclusion and described the grains as 3-porate with an unsculptured sexine. However, Robbrecht (1980) found several sexine types within the tribe. Moreover, Tilney \& van Wyk (1997) found pollen morphological support for the division of Canthium s.s. into three subgenera. Other studies also reveal pollen morphological variation within the Vanguerieae, although the tribe is still considered to be stenopalynous (Verdcourt 1987, Igersheim 1989).

The inside ornamentation of pollen grains in Rubiaceae is known to have systematic value, as first mentioned by French researchers (e.g. Malplanche 1971, Lobreau-Callen 1978, Van Campo 1978, Keddam-Malplanche 1980). Since Huysmans et al. (1994) described a new method for breaking pollen grains with glass beads, observations of the inside of the grains became more accessible (e.g. Jansen et al. 1996, De Block \& Robbrecht 1998, Bosser \& Lobreau-Callen 1998, Huysmans 1998). New features, such as different 
ornamentation types of the inner nexine and the large diversity of endoapertures, have shown their taxonomic importance. This is demonstrated for example in the Coptosapelteae (Huysmans et al. 1993, 1994) and in the Isertieae s.l. of which characters from the inside of the pollen were included for the first time in a cladistic analysis (Huysmans et al. 1998). In Vanguerieae, however, inside observations of pollen grains were only made for the small genus Tapiphyllum (Havard \& Verdcourt 1987) and few other representatives of the tribe (Igersheim 1989).

The present study gives a detailed pollen morphological description of selected species of the Vanguerieae, including observations of the inside ornamentation of the pollen grains.

\section{MATERIAL AND METHODS}

Pollen of 30 species out of 16 genera were removed from herbarium specimens at the National Botanic Garden of Belgium (BR) and were acetolysed following the method of Reitsma (1969). The specimens investigated are listed separately at the end of this paper. LM preparations were made in glycerine jelly. For SEM observations, pollen grains were mounted on an aluminium stub, coated with gold and observed with a JEOL JSM-5800 LV or JSM-6400. Pollen grains were broken using glass beads (Huysmans et al. 1994).

The polar axis and equatorial diameter were measured on ten grains in equatorial view with LM using a camera lucida. Other measurements were made on SEM-micrographs.

Terminology follows the Glossary of Pollen and Spore Terminology (Punt et al. 1994). The terminology of pollen shape in polar
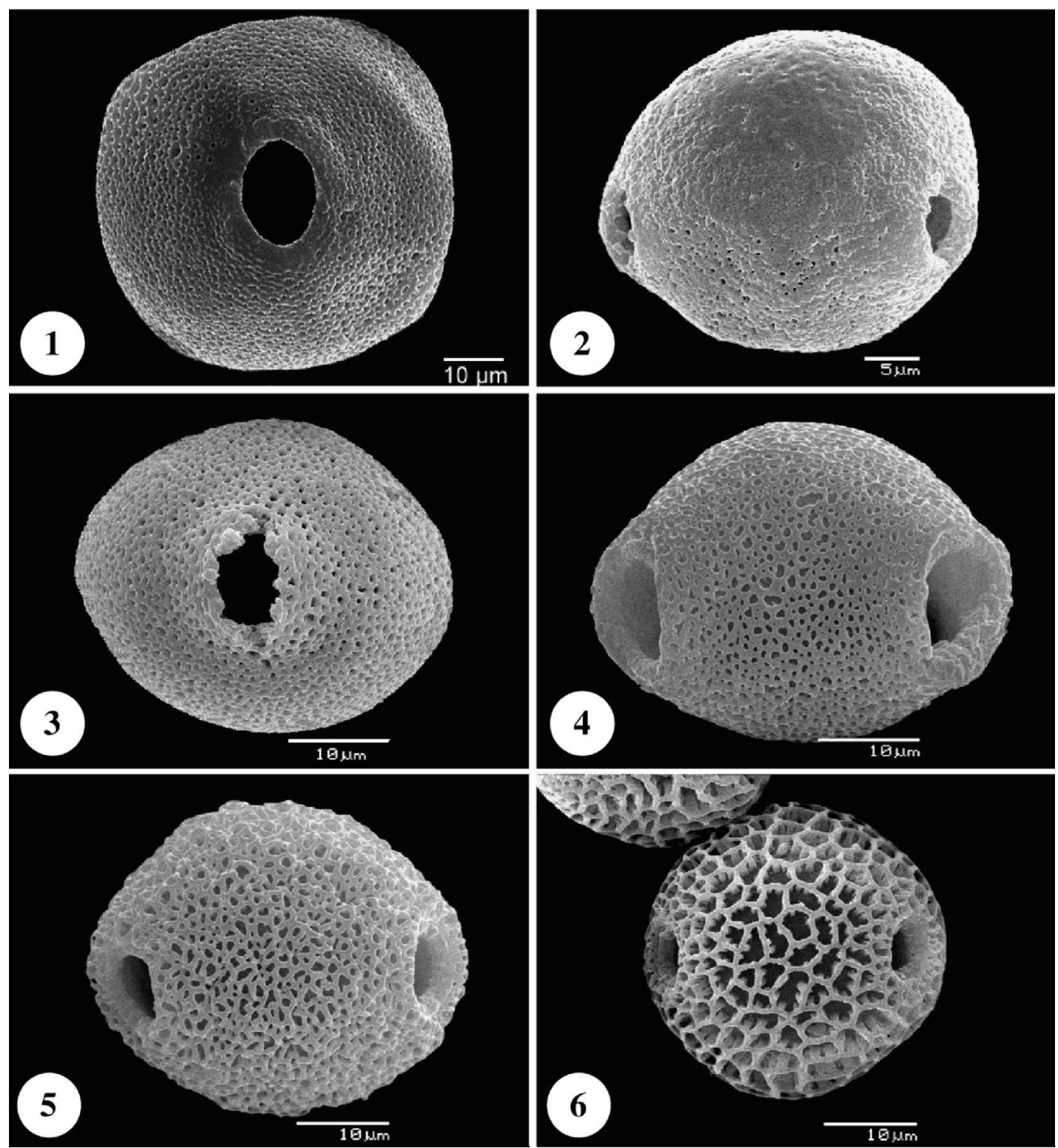

Figs. 1-6. Pollen in equatorial view. SEM. (1) Cuviera longiflora, perforate spheroidal grain with congruent apertures; (2) Canthium parasiebenlistii, suboblate shape, microverrucae (detail in Fig. 28) in bands around psilate apoporium; (3) Pyrostria bibracteata, suboblate perforate grain; (4) Psydrax horizontalis, suboblate reticulate grain; (5) Keetia hispida, idem; (6) Psydrax subcordata var. subcordata, spheroidal reticulate pollen. 



Figs. 7-14. Pollen in polar view. SEM. (7) Canthium setiflorum, amb view circular, perforated sexine; (8) Pyrostria bibracteata, amb view circular, perforate tectum; (9) Canthium parasiebenlistii; polar view circular, granules (detail in Fig. 28) in bands around psilate apoporium; (10) Pygmaeothamnus zeyheri, circular amb view, perforate sexine with psilate apoporium; (11) Lagynias pallidiflora, amb view nearly circular, perforate sexine; (12) Fadogia schmitzii, polar view triangular with convex sides, perforate tectum; (13) Tapiphyllum cinerascens var. laetum, idem; (14) Psydrax horizontalis, amb view triangular with convex sides, reticulate sexine. 





view follows Reitsma (1970). Terms for shape classes in equatorial view are adopted from Erdtman (1971).

The measurements are always mean values. A summary of the pollen morphological features per species is listed in Table I.

\section{RESULTS}

\section{Size}

Pollen grains are generally medium sized (P: $44.9 \mu \mathrm{m}$ and E: $48.9 \mu \mathrm{m})$. The largest pollen grains are observed in Cuviera nigrescens (P: $65.1 \mu \mathrm{m}, \mathrm{E}: 67.1 \mu \mathrm{m})$, the smallest grains in Canthium mundianum and C. parasiebenlistii (P: ca $29 \mu \mathrm{m}, \mathrm{E}$ : ca $32.5 \mu \mathrm{m})$.

\section{Shape}

Pollen grains are oblate spheroidal in $57 \%$ of the specimens investigated, such as in Cuviera longiflora (Fig. 1). Suboblate pollen grains are found in Canthium subg. Afrocanthium (Fig. 2) and subg. Bullockia, Pyrostria (Fig. 3), Keetia (Fig. 4), and Psydrax horizontalis (Fig. 5), while other species have spheroidal pollen, such as Cuviera longiflora (Fig. 1), Fadogia schmitzii and Psydrax subcordata var. subcordata (Fig. 6). The specimen of Vangueriopsis sp. investigated is the only one with prolate spheroidal pollen. The polar view of the grains is circular, e.g. in Canthium setiflorum (Fig. 7), Pyrostria bibracteata (Fig. 8), Canthium parasiebenlistii (Fig. 9), Pygmaeothamnus zeyheri (Fig. 10), or triangular with convex sides, e.g. in Lagynias pallidiflora (Fig. 11), Fadogia schmitzii (Fig. 12), Fadogiella stigmatoloba (Fig. 13), and in Psydrax horizontalis (Fig. 14).

\section{Apertures}

Pollen are (2)-3-(4)-zonoaperturate. The apertures are generally compound consisting of two units. Congruent apertures are sometimes observed, e.g. in Cuviera longiflora (Fig. 1), and sometimes in Psydrax (Fig. 24) and in Pyrostria.

\section{Ectoaperture}

Elongated ectopori are frequently present within the Vanguerieae. The ends of the ectopori are usually obtuse, e.g. in Ancylanthos rubiginosus (Fig. 16) and Tapiphyllum cinerascens var. laetum (Fig. 17), or acute such as in specimens investigated of Lagynias pallidiflora (Fig. 18) and Canthium inerme (Figs. $19 \& 20$ ). The tribe sometimes also shows oval ectopori, e.g. Rytigynia verruculosa (Fig. 23) and Psydrax horizontalis (Fig. 24), or circular ectopori in for instance Canthium lactescens (Fig. 25) and Psydrax subcordata var. subcordata (Fig. 26). Ectocolpi within the Vanguerieae are scarcely present and always short with obtuse ends (e.g. Vangueria infausta) or acute ends, such as in Fadogia stigmatoloba (Fig. 15). The margin of the ectoaperture is often obviously demarcated, except in Canthium setiflorum (Fig. 21) and Keetia gueinzii (Fig. 22); sometimes the ectoaperture has irregular margins because of sexine bulges, especially in Canthium lactescens (Fig. 25) and Canthium mundianum. The largest ectoapertures are observed in Cuviera nigrescens, Pachystigma pygmaeum, Lagynias pallidiflora and Psydrax horizontalis (length ca $16.5 \mu \mathrm{m}$; width ca $10.5 \mu \mathrm{m})$; the smallest ones in Canthium parasiebenlistii and Canthium mundianum (length ca $5 \mu \mathrm{m}$; width ca $4 \mu \mathrm{m})$. Ectoaperture membranes are usually covered with few microverrucae (e.g. Fig. 15). However, in species of Rytigynia and Vangueriopsis these structures are absent. The aperture membrane is sometimes perforated (Fig. 19) or covered with sexine elements in Canthium inerme (Fig. 20).

\section{Endoaperture}

The endoaperture, which is often incongruent with the ectoaperture, is circular in Keetia (Fig. 22) and sometimes in Canthium lactescens (Fig. 25), Psydrax (Fig. 26) and in Pyrostria; usually the endoaperture is elongated, e.g. Cuviera (Fig. 1), or rectangular in Fadogiella stigmatoloba (Fig. 15) and Tapiphyllum cinerascens var. laetum (Fig. 17).

\section{Sexine}

Pollen in the Vanguerieae are mostly tectate, although semitectate in Keetia (Fig. 33) and Psydrax (Figs. 6, 26 \& 34). The tectum is always even and smooth (except in Canthium parasiebenlistii, Figs. 2, 9 \& 28), but a bumpy tectum is observed in Keetia cornelia and $K$. hispida (Fig. 33). Perforate taxa are common within the Vanguerieae, such as in Canthium (Fig. 27), Vangueria, Fadogia, Meyna, Cuviera, and Pygmaethamnus. Some of these genera have baculae in the perforations (Figs. 29-31). Perforations are often unequally distributed, variable in size, and have a more or less circular shape. Very small perforations are found in the genera Canthium and Vangueria. Some of the perforated taxa have a psilate tectum on their poles, such as in Canthium parasiebenlistii (Fig. 28), Pygmaeothamnus zeyheri (Fig. 10), and Canthium mundianum. The former species is characterised by microverrucae which are densely grouped in bands around the apo- and mesoporia (Figs. 2, 9 $\&$ 28). A reticulate sexine type is illustrated by Keetia

Figs. 15-26. Detail of apertures. SEM. (15) Fadogiella stigmatoloba, small ectocolpus, rectangular endoporus; (16) Ancylanthos rubiginosus, elongated porus with obtuse ends, endoporus rectangular with curved margins; (17) Tapiphyllum cinerascens var. laetum, elongated ectoporus with obtuse ends, rectangular endoporus; (18) Lagynias pallidiflora, elongated ectoporus with acute ends, endoaperture rectangular; (19) \& (20) Canthium inerme, elongated ectoporus with acute ends, membrane of ectoporus perforated (arrows; Fig. 19) or covered with sexine elements (Fig. 20); (21) Canthium setiflorum, elongated ectoporus with diffuse ends; (22) Keetia gueinzii, idem; (23) Rytigynia verruculosa, elongated to oval ectoporus, small granules on the inside of the lumina (arrows); (24) Psydrax horizontalis, oval ectoporus congruent with endoporus, margin present; (25) Canthium lactescens, sexine bulges form irregular margin of circular ectoporus, circular endoporus; (26) Psydrax subcordata var. subcordata, circular ecto- and endoporus. 


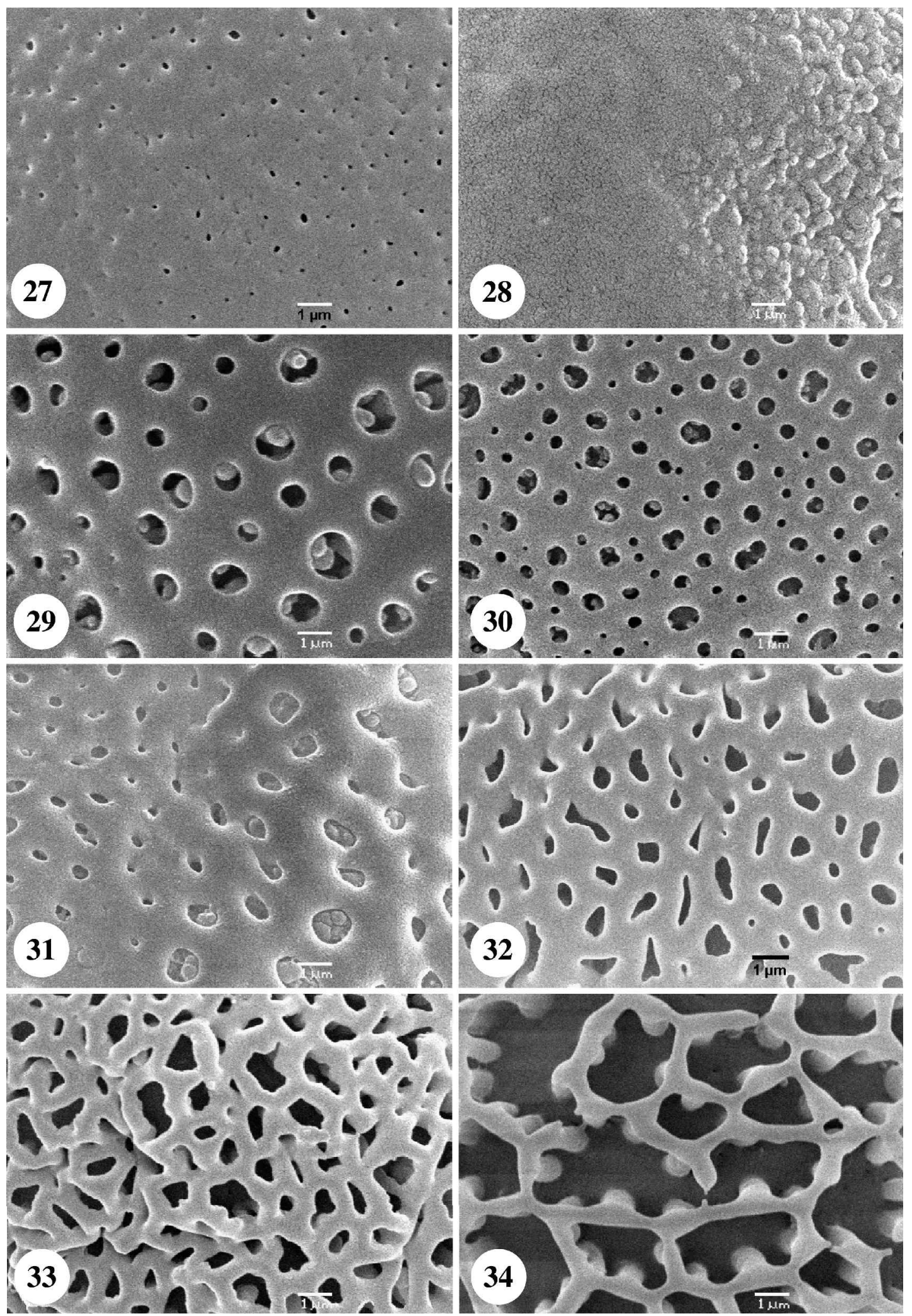

Figs. 27-34. SEM. Detail of different sexine types. (27) Canthium inerme, perforated mesoporium with circular perforations; (28) Canthium parasiebenlistii, psilate apoporium with detail of microverrucae; (29) Fadogia schmitzii, presence of one or more baculae in the perforation of apoporium; (30) Tapiphyllum cinerascens var. laetum, idem; (31) Vangueriopsis sp., idem; (32) Keetia gueinzii, perforate to reticulate mesoporium with irrgular lumina; (33) Keetia hispida, bumpy reticulate apoporium; (34) Psydrax subcordata var. subcordata, reticulate mesoporium with large polygonal lumina. 



Figs. 35-42. Inner nexine ornamentation and costae (arrows point to poles). (35) Cuviera nigrescens, two crescent-shaped costae perpendicular to ectoaperture; LM. (36) Vangueria infausta; LM. 37-42. SEM. (37) Canthium ciliatum, inner nexine generally smooth, scabrae concentrated near endoaperture, two crescent-shaped costae; (38) Canthium setiflorum, idem; (39) Fadogia schmitzii, idem; (40) Pygmaeothamnus zeyheri, scabrae concentrated near endoaperture, the two endexine thickenings of costa become fused on equator; (41) Keetia hispida, elliptical to circular costa; (42) Psydrax subcordata var. subcordata, circular costa with granular surface. 
cornelia and K. hispida (Fig. 33), Psydrax (Figs. 6, 14 \& 34), and Rytigynia verruculosa. The latter species has granules at the inside of the lumina (Fig. 23). The shape of the lumina is elongated in Keetia gueinzii (Fig. 32), irregular in K. hispida (Fig. 33) or polygonal in Psydrax subcordata var. subcordata (Fig. 34). An intermediate state between perforate and reticulate pollen grains is shown by Keetia gueinzii (Fig. 32). A margo is present in pollen of Psydrax horizontalis (Fig. 24), Pyrostria sp., and Vangueriopsis sp.

\section{Inner nexine ornamentation and stratification of pollen wall}

The nexine is generally smooth with scabrae usually concentrated near the endoapertures in e.g. Canthium ciliatum (Fig. 37), Pygmaeothamnus zeyheri (Fig. 40), and in Canthium setiflorum (Fig. 45). However, the whole surface of the inner nexine in Keetia hispida is covered with equally distributed scabrae (Fig. 43). The costae, which lie perpendicular to the ectoaperture (Figs. $35 \& 36$ ), are always present in the tribe. Costae have the shape of two crescents oriented toward another in e.g. Canthium ciliatum (Fig. 37), Canthium setiflorum (Fig. 38), Fadogia schmitzii (Fig. 39), and in Pygmaeothamnus zeyheri (Fig. 40); costae are elliptical to circular in Keetia hispida (Fig. 41), or circular in species of Psydrax (Fig. 42) and Pyrostria.

Sexine is mostly thicker than nexine (mean ratio 1.78 ). The highest ratio is nearly 2.75 in Keetia cornelia; the lowest values (ca 1) are observed in Cuviera longiflora, Fadogiella stigmatoloba (Fig. 46), and Tapiphyllum cinerascens var. laetum. Mean length of the columellae is $0.74 \mu \mathrm{m}$. The shortest columellae are present in Vangueriopsis sp. (ca $0.05 \mu \mathrm{m}$ ), while Keetia gueinzii has long columellae (ca $2.7 \mu \mathrm{m}$; Fig. 44). Wall sections show a high columella density in e.g. Fadgiella stigmatoloba (Fig. 46) and Lagynias pallidiflora and a low density in Psydrax (Fig. 42) and Keetia (Fig. 44). The thickness of the tectum is rather homogeneous (on average $0.74 \mu \mathrm{m}$ ). The columella/tectum ratio is high in Psydrax subcordata var. subcordata (Fig. 42) and Keetia gueinzii (ca 2.4; Fig. 44), while much lower values occur in Canthium ciliatum and Vangueriopsis sp. (ca 0.1).

\section{DISCUSSION}

\section{Aperture configuration}

Pollen grains in Vanguerieae are nearly always 3-zonoaperturate, which is the most common pollen class within the Rubiaceae (Erdtman 1952, Robbrecht 1988). The presence of 2- or 4-aperturate pollen in the tribe is exceptional and occurs in some grains of Pyrostria sp., Canthium mundianum, Pachystigma pygmaeum, Tapiphyllum cinerascens var. laetum, and Vangueria infausta. Pollen with 2 or 4 apertures were also observed in Canthium and Psydrax by Tilney \& van Wyk (1997). Our results clearly demonstrate that pororate pollen grains are most common within the Vanguerieae, because the ectoaperture (usually a porus) is often not congruent with the aperture lying beneath it. This is not in agreement with earlier pollen morphological studies which described porate pollen grains as the most common type within the tribe (e.g. Verdcourt 1987, Igersheim 1989). Pororate pollen grains are otherwise rare in the Rubiaceae and occur amongst others in Gardenieae-Gardeniinae (Persson 1993), Isertieae (Huysmans et al. 1998) and Coptosapelteae (Huysmans 1998).

The two other pollen classes that occur in the Vanguerieae, namely porate and colporate pollen, are less common. In the latter case, the colpi of the ectoapertures are characteristically short, which is in contrast to most Rubiaceae that have long ectocolpi, such as the related Coffeeae and Pavetteae (Robbrecht 1988, Stoffelen et al. 1997, De Block \& Robbrecht 1998). Within the Vanguerieae, it is sometimes difficult to distinguish ectocolpi from ectopori because the length/width ratio of the ectoapertures of the same specimen sometimes varies around the critical value of two (in e.g. Vangueria). Furthermore, some species of Canthium, show a tendency to even shorter ectoapertures. C. lactescens (Fig. 25) and C. mundianum for example both show inward sexine bulges around the ectoaperture. A second indication of the reduction trend is observed in C. setiflorum, which has a porus membrane that is covered with a sexine layer (Fig. 21). This vague transition between the sexine and the porus membrane is also observed in Keetia gueinzii (Fig. 22). Canthium inerme shows a third evidence for the shrinking ectoporus length because it sometimes shows sexine elements on the porus membrane (Fig. 20). Moreover, the porus membrane is sometimes perforated (confer perforations in tectum: Fig. 19). Canthium (Fig. 25), Psydrax (Fig. 26), Pyrostria and Keetia have circular ectoapertures. Hence, it is clear that pollen of the tribe is characterised by a continuous transition between short ectocolpi, elongated ectopori and circular ectopori. This evolutionary tendency is also discussed by Lobreau-Callen (1978) for Rubiaceae and was also briefly mentioned by Robbrecht (1980).

Most Rubiaceae, such as the Pavetteae (De Block \& Robbrecht 1998) and Coffeeae (Stoffelen et al. 1997), have compound apertures consisting of ecto-, meso-, and endoaperture (Lobreau-Callen 1978). In the Vanguerieae, however, the structure of the compound aperture is very difficult to observe on the basis of LM and SEM. Two interpretations are possible:

1. Compound apertures consist of two strata, an ectocolpus/ porus and an endoporus (opening in the pollen wall). The area delimited by the costa is not considered as an aperture.

2. The area within the costa is considered as the endoaperture; the opening in the pollen wall then corresponds to the mesoporus.

According to the latter interpretation, the endo- and mesoaperture are congruent when a circular costa/ectoaperture is present. We believe that the first hypothesis is most plausible for the Vanguerieae because the region defined by the costa is not likely to be a specialised region of the sporoderm (Punt et al. 1994). Furthermore, in case of a circular costa/ectoaperture, the congruence between the mesoporus and the endoaperture (and possibly the ectoporus) is hard to prove on the basis of morphological 
Table I. Summary of the pollen morphological features of the Vanguerieae for all species studied.

$+:$ present, -: absent, $\Delta \mathrm{C}$ : amb triangular with convex sides, $\Delta \mathrm{S}$ : amb triangular with straight sides, $\mathrm{A}$ : acute, CI: circular, $2 \mathrm{CO}: 2$ crescentshaped, COLP: zonocolporate, CP: circular porus, D: distinct, ECOL: ectocolpus, ELP: elongated porus, E: elliptical, IR: irregular,

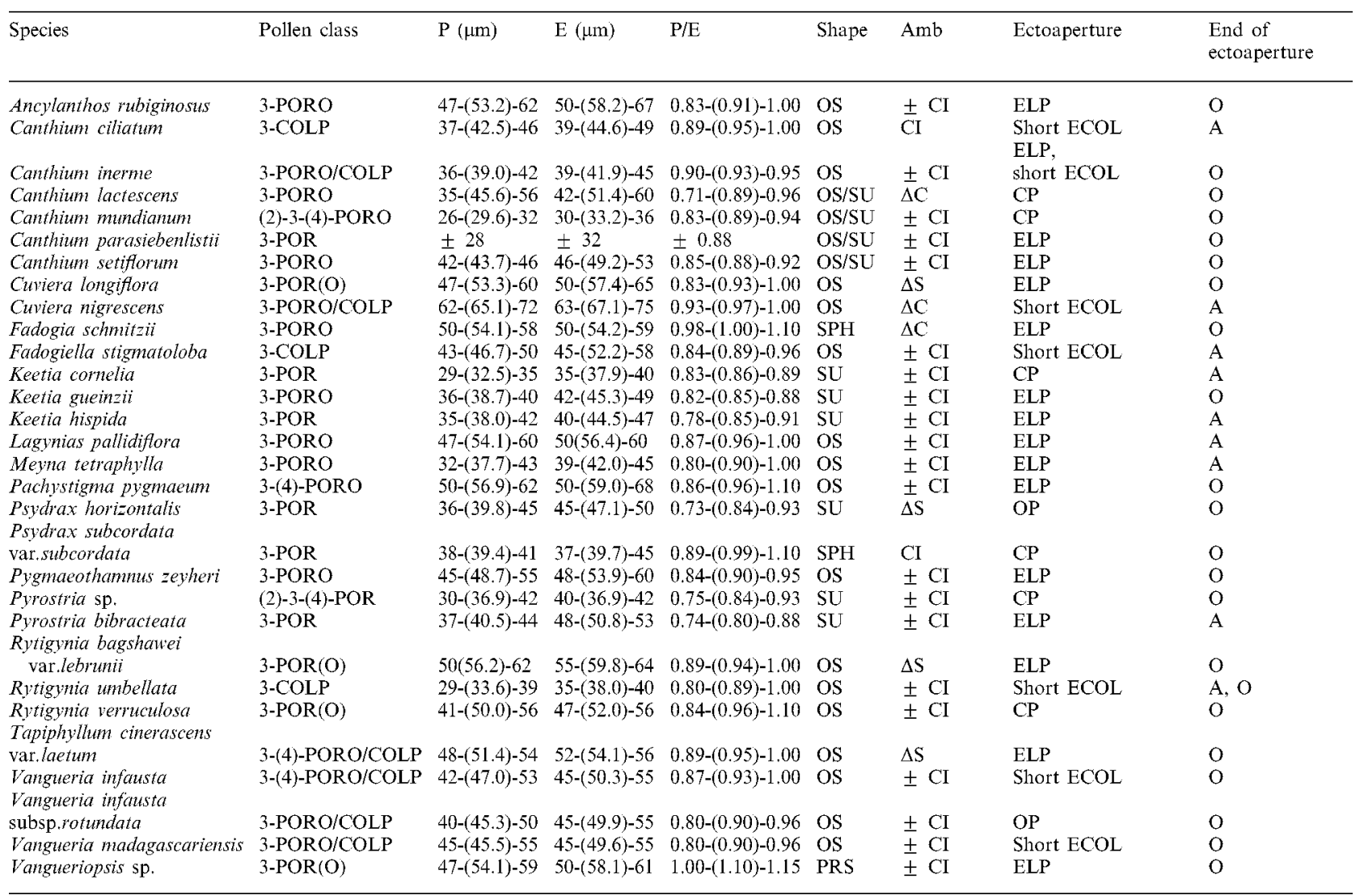

observations only. Only additional TEM studies may clarify this.

Since the endoapertures in our circumscription are usually not entirely visible on broken grains in SEM, the shape is described based on external observations. This sometimes gives an unusual picture of the endoaperture, such as a rectangular shape with straight (Figs. $15 \& 17$ ) or curved (Figs. $16 \& 18$ ) borders. Only when the endoapertures are entirely visible from the outside of a pollen grain, it is clear that they are circular (Figs. $25 \& 26$ ), elliptical (Fig. 1) or oval (Figs. 23 \& 24).

\section{Sexine pattern}

Pollen of the Vanguerieae have two main sexine types. Perforate pollen grains are most common. On the basis of the size of the perforations, one can easily distinguish Canthium and Vangueria from the remaining perforated taxa (Figs. 29-31); both genera have very small perforations (Tilney \& van Wyk 1997, Fig. 27). In Canthium parasiebenlistii (Fig. 2), C. mundianum, and Pygmaeothamnus zeyheri (Fig. 10), perforations are present in the mesoporia, but absent on the poles (psilate apoporium). Canthium parasiebenlistii is characterised by circular bands of microverrucae around the apo- and mesoporia (Figs. $2 \& 9$ ). The perforations are nearly always unequally distributed, they have a circular or elongated shape, and usually vary in size (Figs. $27 \& 29-31$ ). The presence of baculae in the perforations is a rather unusual feature in rubiaceous pollen, but clearly present in most of the perforate taxa with larger perforations (see also Igersheim 1989, Figs. 29-31). Perforations with baculae were also observed by Huysmans (1998) in some Simireae and Cinchoneae. The perforations within the Coffeeae differ from those in the Vanguerieae by their elongated and irregular shape (Stoffelen et al. 1997). Pollen of Keetia and Psydrax are distinguished from other Vanguerieae by their reticulate sexine ( see also Tilney \& van Wyk 1997). In contradiction to the observations of these authors, who found oblate pollen with a finely reticulate tectum in Psydrax, we observed that the grains of Psydrax subcordata var. subcordata are spheroidal and have very large polygonal lumina (on average $2.75 \mu \mathrm{m}$ on apoporium and $3 \mu \mathrm{m}$ on mesoporium; Fig. 34). However, according to the same authors, this sexine pattern is characteristic of Keetia. Furthermore, they did not observe a bumpy tectum in Keetia.

\section{Inner nexine ornamentation}

Pollen grains in the tribe generally have a smooth inner surface with scabrae near the endoapertures, in contrast to most of the Rubiaceae which have a granular inner nexine 
LUM: inside of lumen, MR: microreticulate, O: obtuse, OP: oval porus, OS: oblate spheroidal, P: perforate, POR: zonoporate, PORO: zonopororate, PRS: prolate spheroidal, PS: psilate, R: reticulate, RECP: rectangular porus, S: sharp, SPH: spheroidal, SU: suboblate, T: tectum, V: vague.

\begin{tabular}{|c|c|c|c|c|c|c|c|c|c|c|c|}
\hline $\begin{array}{l}\text { Margin } \\
\text { ectoaperture }\end{array}$ & Endoaperture & $\begin{array}{l}\text { Microverrucae } \\
\text { on }\end{array}$ & $\begin{array}{l}\text { Sexine } \\
\text { type }\end{array}$ & Baculae & Costa & $\begin{array}{l}\text { Columellae } \\
(\mu \mathrm{m})\end{array}$ & $\begin{array}{l}\text { Tectum } \\
(\mu \mathrm{m})\end{array}$ & Col./tect. & $\begin{array}{l}\text { Sexine } \\
(\mu \mathrm{m})\end{array}$ & $\begin{array}{l}\text { Nexine } \\
(\mu \mathrm{m})\end{array}$ & $\begin{array}{l}\text { Sex. } \\
\text { /nex. }\end{array}$ \\
\hline $\mathrm{D}$ & $\pm \mathrm{RECP}$ & EP & $\mathrm{P}$ & - & $\mathrm{E}$ & 1.14 & 0.71 & 1.61 & 1.85 & 1.14 & 1.62 \\
\hline $\mathrm{D}$ & RECP & ECOL & $\mathrm{P}$ & - & $2 \mathrm{CL}$ & 0.35 & 0.57 & 0.61 & 0.96 & 0.70 & 1.37 \\
\hline IR & $\pm \mathrm{CP}$ & $\mathrm{EP}, \mathrm{ECOL}$ & $\mathrm{P}$ & - & $\mathrm{E}$ & 0.24 & 0.58 & 0.41 & 0.82 & 0.70 & 1.17 \\
\hline IR & $\mathrm{CP}, \mathrm{ELP}$ & $\mathrm{EP}$ & $\mathrm{P}$ & - & $\mathrm{E}$ & 0.59 & 0.71 & 0.83 & 1.30 & 0.59 & 2.20 \\
\hline IR & ELP & $\mathrm{EP}$ & $\mathrm{P}$ & - & $\mathrm{C}$ & 0.31 & 0.23 & 1.35 & 0.54 & 0.31 & 1.74 \\
\hline $\mathrm{D}$ & CP & $\mathrm{T}$ & P, PS & - & $?$ & $?$ & $?$ & $?$ & $?$ & $?$ & $?$ \\
\hline $\mathrm{V}$ & RECP & - & $\mathrm{P}$ & - & $2 \mathrm{CL}$ & 0.45 & 0.63 & 0.71 & 1.08 & 0.55 & 1.96 \\
\hline D & CP, ELP & - & $\mathrm{P}$ & + & $\mathrm{C}$ & 0.66 & 0.75 & 0.88 & 1.41 & 1.5 & 0.94 \\
\hline $\mathrm{D}$ & ELP & $\mathrm{EP}, \mathrm{ECOL}$ & $\mathrm{P}$ & + & $2 \mathrm{CL}$ & 0.50 & 0.50 & 1.00 & 1.00 & 0.60 & 1.67 \\
\hline $\mathrm{D}$ & ELP & EP & $\mathrm{P}$ & + & $2 \mathrm{CL}$ & 0.70 & 0.80 & 0.86 & 1.50 & 0.80 & 1.86 \\
\hline $\mathrm{D}$ & RECP & ECOL & $\mathrm{P}$ & - & $2 \mathrm{CL}$ & 0.80 & 1.00 & 0.80 & 1.80 & 1.80 & 1.00 \\
\hline IR & CP & EP & $\mathbf{P}$ & - & $\mathrm{C}$ & 1.20 & 1.00 & 1.20 & 2.20 & 0.80 & 2.75 \\
\hline $\mathrm{D}$ & CP & $\mathrm{EP}$ & $\mathrm{P}, \mathrm{R}$ & - & $\mathrm{C}$ & 2.73 & 1.14 & 2.39 & 3.86 & 1.59 & 2.42 \\
\hline $\mathrm{D}$ & $\pm \mathrm{CP}, \mathrm{ELP}$ & - & $\mathrm{R}$ & - & $\mathrm{C}$ & 1.05 & 0.79 & 1.33 & 1.84 & 1.05 & 1.75 \\
\hline $\mathrm{D}$ & \pm RECP & $\mathrm{EP}$ & $\mathrm{P}$ & + & $2 \mathrm{CL}$ & 1.05 & 0.79 & 1.33 & 1.84 & 1.05 & 1.75 \\
\hline IR & $\pm \mathrm{CP}$ & $\mathrm{EP}$ & $\mathrm{P}$ & - & $\mathrm{E}$ & 0.53 & 0.53 & 1.00 & 1.06 & 0.53 & 2.00 \\
\hline $\mathrm{D}$ & $\overline{\mathrm{OP}}$ & $\mathrm{EP}$ & $\mathrm{P}$ & - & $\mathrm{C}$ & 0.60 & 0.40 & 1.50 & 1.00 & 0.40 & 2.50 \\
\hline $\mathrm{D}$ & ELP & - & $\mathrm{R}$ & - & $\mathrm{E}, \mathrm{C}$ & $?$ & $?$ & $?$ & $?$ & $?$ & $?$ \\
\hline $\mathrm{D}$ & $\mathrm{CP}$ & - & $\mathrm{R}$ & - & $\mathrm{C}$ & 1.86 & 0.78 & 2.38 & 2.64 & 1.09 & 2.42 \\
\hline $\mathrm{D}$ & RECP & EP & P, PS & + & $2 \mathrm{CL}$ & 0.45 & 0.63 & 1,21 & $?$ & $?$ & $?$ \\
\hline IR & CP & $\mathrm{EP}$ & $\mathrm{P}$ & - & $\mathrm{C}$ & 0.80 & 0.60 & 1.33 & 1.40 & 0.60 & 2.33 \\
\hline IR & ELP & - & $\mathrm{P}$ & - & $\mathrm{E}$ & 0.63 & 0.47 & 1.34 & 1.08 & 0.47 & 2.34 \\
\hline $\mathrm{D}$ & ELP & - & $\mathrm{P}$ & - & $2 \mathrm{CL}$ & 0.94 & 0.59 & 1.59 & 1.53 & 0.94 & 1.63 \\
\hline $\mathrm{D}$ & ELP & - & $\mathrm{P}$ & - & $?$ & 0.38 & 1.15 & 0.33 & 1.53 & 0.96 & 1.59 \\
\hline $\mathrm{D}$ & $\mathrm{CP}, \mathrm{OP}$ & LUM & $\mathrm{R}$ & - & $\mathrm{C}$ & 0.25 & 0.75 & 0.33 & 1.00 & 0.75 & 1.33 \\
\hline $\mathrm{D}$ & $\pm \mathrm{RECP}$ & $\mathrm{EP}, \mathrm{ECOL}$ & $\mathrm{P}$ & + & $2 \mathrm{CL}$ & 0.59 & 0.59 & 1.00 & 1.18 & 1.18 & 1.00 \\
\hline $\mathrm{D}$ & $\pm \mathrm{RECP}$ & $\mathrm{EP}, \mathrm{ECOL}$ & $\mathrm{P}$ & - & $2 \mathrm{CL}$ & 0.63 & 0.63 & 1.00 & 1.26 & 0.75 & 1.68 \\
\hline $\mathrm{D}$ & RECP & $\mathrm{EP}, \mathrm{ECOL}$ & $\mathrm{P}$ & - & $2 \mathrm{CL}$ & 0.63 & 0.63 & 1.00 & 1.25 & 0.47 & 2.66 \\
\hline D & $\pm \mathrm{RECP}$ & $\mathrm{EP}, \mathrm{ECOL}$ & $\mathrm{P}$ & - & $2 \mathrm{CL}$ & 0.74 & 0.74 & 1.00 & 1.48 & 1.11 & 1.33 \\
\hline $\mathrm{D}$ & ELP & - & $\mathrm{P}$ & + & $\mathrm{C}$ & 0.06 & 0.65 & 0.09 & 0.71 & 0.59 & 1.20 \\
\hline
\end{tabular}

(Robbrecht 1988). Sometimes the whole inner surface is covered with scabrae (Fig. 43). The presence of a costa in all the specimens investigated is typical of pollen of the Vanguerieae. Correlated with the shape of the ectoaperture, three costa types are observed. In a first type, present in pollen with short ectocolpi or elongated ectopori (e.g. in Fadogia schmitzii), two crescent-shaped thickenings occur parallel to the equator plane (Figs. $35 \& 36$ ). These thickenings may be enlarged on the mesoporium/colpium side by the presence of verrucae in e.g. Pygmaeothamnus zeyheri (Fig. 40). When the two thickenings become fused, an elliptical costa (second type) is formed, which is found for instance in Canthium lactescens. The elliptical costa usually is correlated with elongated (or more or less elliptical) ectopori. The third costa type, possibly evolved by shrinking of the elliptical costa, has a circular shape. A transition is observed in Keetia hispida (Fig. 41). The circular costae occur in Keetia, Psydrax and Pyrostria, the same taxa that also have circular ectopori. This costa type is also characterised by its granular surface, in contrast to the first two costa types which are more massive and have a coarse surface (Fig. 42).

Costae are also seen in many other tribes of the family, such as the related Pavetteae (De Block \& Robbrecht 1998) and Gardenieae (Persson 1993), or the more distantly related Coptosapelteae (Huysmans 1998).

\section{Stratification of the pollen wall}

Rubiaceae are characterised by a sexine/nexine ratio $\geq 1$ (e.g. Huysmans 1998). This is also observed in the study group, which has a mean ratio of 1.75 . Variation in the columellae is found in the length (on average $0.75 \mu \mathrm{m}$ ) and the density. Vangueriopsis sp. illustrates short columellae, while Keetia gueinzii has long columellae (Fig. 44). In Ancylanthos rubiginosus, Canthium setiflorum and Lagynias pallidiflora, the columellae are grouped closely together, while Keetia and Psydrax have widely scattered columellae. Since the thickness of the tectum layer is rather constant, the columella/tectum ratio varies together with the length of the columellae.

\section{Dispersal of the pollen grains}

Nearly all rubiaceous pollen is dispersed as monads. Pollen grains are united in permanent tetrads in some genera of Gardenieae and in Gleasonia of the Henriquezieae (Robbrecht 1988, Persson 1993, Robbrecht \& Puff 1986, Robbrecht et al. 1996). In the genus Massularia (Gardenieae) the tetrads are further united into massulae (Persson 1993), which is a very rare feature within the angiosperms (Walker \& Doyle 1975). Massulae were also observed by Igersheim (1989) in Psydrax subgenus Psydrax and in 

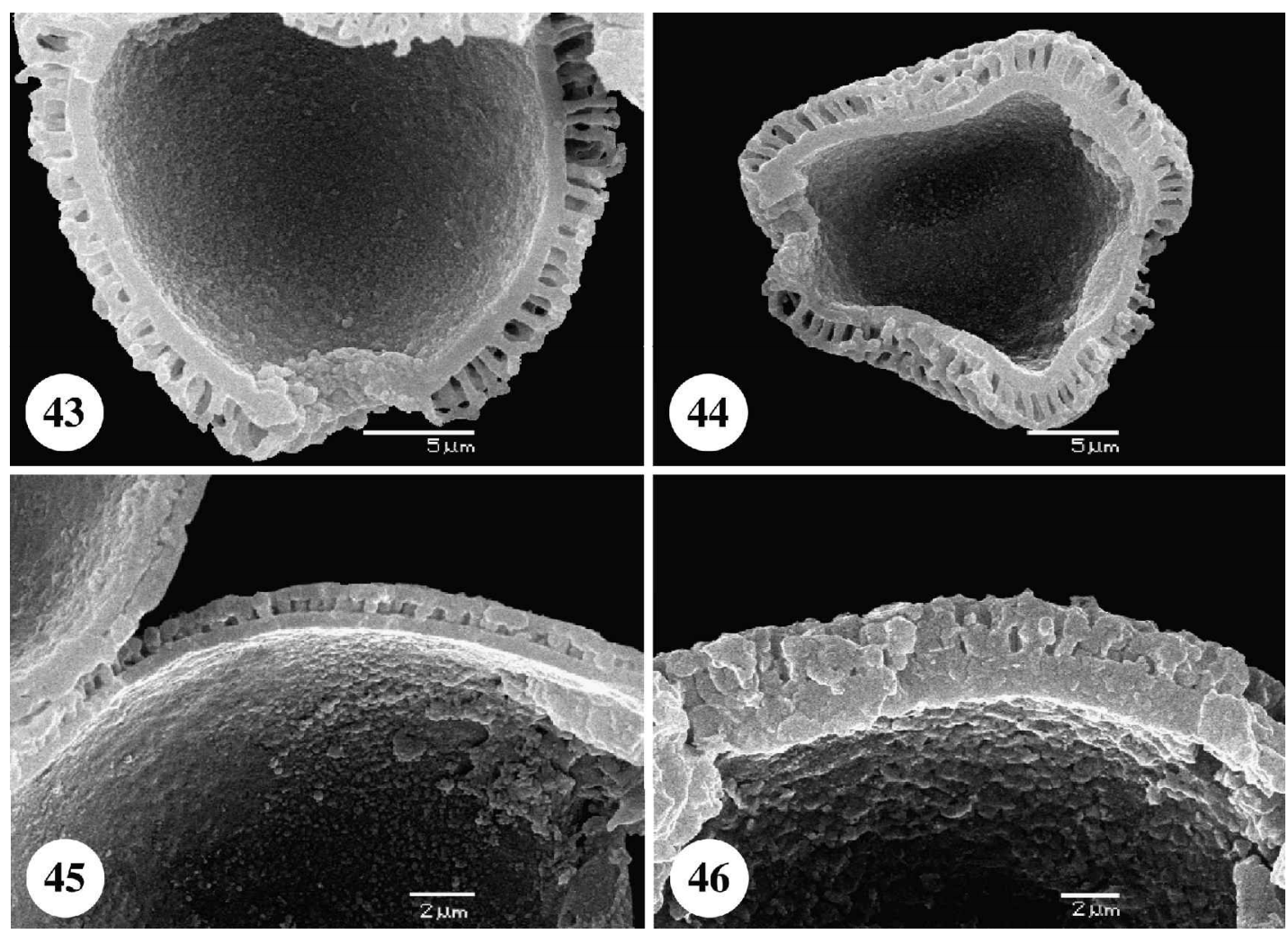

Figs. 43-46. Pollen wall stratification. (43) Keetia hispida, inner nexine wholly covered with scabrae, long and widely spread columellae; (44) Keetia gueinzii, idem; (45) Canthium setiflorum, short columellae standing close to each other; (46) Fadogiella stigmatoloba, nexine has nearly the same thickness as the sexine, columellae standing close to each other.

Keetia. According to Igersheim, acetolysed pollen of these genera are held together by sexine bridges so that large aggregates of pollen can be visualised by SEM-micrographs. In the specimens of Psydrax subcordata var. subcordata and Keetia investigated, however, we found no massulae but monads.

\section{Taxonomic value of pollen morphology within the} Vanguerieae

As already concluded in earlier studies (Verdcourt 1987, Igersheim 1989), pollen morphology does not provide much useful information for the generic delimitations within the Vanguerieae. Nevertheless, based upon an investigation of South African representatives, Tilney \& van Wyk (1997) defined three subgenera of Canthium sensu Bridson (1992) on the basis of the size and shape of the grains, the exine thickness and the ratio of sexine/nexine. In our study, these features also proved to be systematically informative. Grains of Canthium subgenus Lycioserissa for instance, represented by $C$. ciliatum and $C$. inerme, are oblate spheroidal and their sexine/nexine ratio is rather similar (see Table I). On the other hand, subgenus Bullockia (represented by C. setiflorum) and subgenus Afrocanthium (represented by C. lactescens, C. mundianum and C. parasiebenlistil have pollen which tend to be suboblate. Furthermore, the sexine of these two subgenera is about two times the thickness of the nexine. Subgenus Afrocanthium differs from subgenus
Bullockia in the smaller mean size (no specimens of C. subgenus Canthium were available to us). Hence, this study corraborates some of Bridson's hypothesis, e.g. a close relationship between Keetia and Psydrax, and the division of Canthium s.s. into subgenera. Nevertheless, the delimitation of most of the genera cannot be based on pollen morphology only.

\section{ACKNOWLEDGEMENT}

We thank Marcel Verhaegen for technical assistance during the SEM observations. This research was supported by a grant from the Research Council of the K.U.Leuven (OT/97/23). S. Huysmans is a Postdoctoral Fellow of the Fund for Scientific Research-Flanders (Belgium) (FWO) .

\section{SPECIMENS INVESTIGATED}

All specimens are from the herbarium of the National Botanic Garden of Belgium (BR).

Ancylanthos rubiginosus Desf., ANGOLA: Huila, Quilemba, J.B. Teixeira 2817 (Fig. 16)

Canthium ciliatum (D.Dietr.) Kuntze, SOUTH AFRICA: Zoutpansberg, Farm Rustfontein, H.J. Schlieben 7351 (Fig. 37)

C. inerme (L.f.) Kuntze, ZIMBABWE: Umtali, A.C. Chase 5351 (Figs. 19, 20 \& 27)

C. lactescens Hiern, RWANDA: Muhero, G. Michel 4821 (Fig. 25) 
C. mundianum Cham. \& Schltdl., SOUTH AFRICA: Zoutpansberg, Farm Rustfontein, H.J. Schlieben 7596

C. parasiebenlistii Bridson, TANZANIA: Iringa region, Mufundi, Penny Pennis Farm, R.K. Brummitt et al. 18165 (Figs. 2, 9 \& 28)

C. setiflorum Hiern, ETHIOPIA: Sidamo, J. Ash 2444 (Figs. 7, 21, $38 \& 45)$

Cuviera longiflora Hiern, CONGO-KINSHASA: Yangambi, J. Louis 823 (Fig. 1) \& 1255

C. nigrescens Wernham, NIGERIA: Sapoba, J.D. Kennedy 2319 (Fig. 35)

Fadogia schmitzii Verdc., CONGO-KINSHASA: Kolwezi, Schmitz 2958 (Figs. 12, 29 \& 39)

Fadogiella stigmatoloba (K.Schum.) Robyns, CONGO-KINSHASA: Katanga, Kalukuluku, F. Malaisse 9350 (Figs. 15 \& 46)

Keetia cornelia (Cham. \& Schltdl.) Bridson, IVORY COAST: Comoé river, Bouin, C. Geerling \& J. Bokdam 2153

K. gueinzii (Sond.) Bridson, CONGO-KINSHASA: Yalibwa, J. Louis 1198 (Figs. 22, 32 \& 44)

K. hispida (Benth.) Bridson, CONGO-KINSHASA: Yangambi, J. Louis 2944 (Figs. 5, 33, 41 \& 43)

Lagynias pallidiflora Bullock, TANZANIA: Mahenge, H.J. Schlieben 2135 (Figs. $11 \& 18$ )

Meyna tetraphylla (Schweinf.) Robyns, SUDAN: Imatong mountains, I. Friis \& K. Vollesen 1185

Pachystigma pygmaeum (Schltr.) Robyns, CONGO-KINSHASA: Katanga, plateau of Marungu, S. Lisowiski 9669

Psydrax horizontalis (Schumach. \& Thonn.) Bridson, IVORY COAST: mount Niangbo, C. Geerling \& J. Bokdam 1035 (Figs. 4, 14 \& 24)

P. subcordata (DC.) Bridson var. subcordata, RWANDA: Rangiro, D. Bridson 337 (Figs. 6, 26, 34 \& 42)

Pygmaeothamnus zeyheri (Sond.) Robyns, SOUTH AFRICA: near Josefsdal (border S. Africa/Swaziland), C. Puff 2631 (Figs. 10 \& 40)

Pyrostria sp., MADAGASCAR: Fianarantsoa Anosimasina, S. Malcomber et al. 1622

P. bibracteata Hiern, TANZANIA: Zanzibar, H.G. Faulkner 2248 (Figs. 3 \& 8)

Rytigynia bagshawei (S. Moore) Robyns var. lebrunii (Robyns) Verdc., BURUNDI: Kayanza, J. Lewalle 2569

R. umbellata (Hiern) Robyns, CONGO-KINSHASA: Katanga, Luiswishi, F. Malaisse 9601

$R$. verruculosa (K.Krause) Robyns, CONGO-KINSHASA: Yangambi, J. Louis 5598 (Fig. 23)

Taphiphyllum cinerascens (Welw. ex Hiern) Robyns var. laetum (Robyns) Verdc., CONGO-KINSHASA: Katanga, Kumanua, F. Malaisse 9658 (Figs. 13, 17 \& 30)

Vangueria infausta Burch., RWANDA: Biumba, Nyarubanga, G. Troupin 8169 (Fig. 36), ZIMBABWE: Delport road E of Salisbury, R.O.B. Rutherford-Smith 350

$V$. infausta subsp. rotundata (Robyns) Verdc., KENYA: Kwale, Longomwagandi Forest, Shimba Hills, F. Magogo \& P. Glover 181

V. madagascariensis J.F. Gmel., CONGO-KINSHASA: Eala, Corbisier 163

Vangueriopsis sp., CONGO-KINSHASA: Yangambi, J. Louis 3379 (Fig. 31)

\section{REFERENCES}

Andersson, L. \& Rova, J. H. E. 1999. The rps 16 intron and the phylogeny of the Rubioideae (Rubiaceae). - Plant Systematics and Evolution 214: 161-186.
Andreasen, K., Baldwin, B. G. \& Bremer, B. 1999. Phylogenetic utility of the nuclear rDNA ITS region in subfamily Ixoroideae (Rubiaceae): comparisons with cpDNA $r b c \mathrm{~L}$ sequence data. Plant Systematics and Evolution 217: 119-135.

Andreasen, K. \& Bremer, B. 1996. Phylogeny of the subfamily Ixoroideae (Rubiaceae). - Opera Botanica Belgica 7: $119-138$.

Bosser, J. \& Lobreau-Callen, D. 1998. Landiopsis Capurion et Bosser, genre nouveau de Rubiacées de Madagascar. Adansonia 20: 131-137.

Bremer, B. 1996. Phylogenetic studies within Rubiaceae and relationships to other families based on molecular data. Opera Botanica Belgica 7: 33-50.

Bremer, B., Andreasen, K \& Olsson, D 1995. Subfamilial and tribal relationships in the Rubiaceae based on $r b c \mathrm{~L}$ sequence data. Annals of the Missouri Botanical Garden 82: 383-397.

Bremer, B. \& Thulin, M. 1998. Collapse of the Isertieae, reestablishment of Mussaendeae, and a new genus of Sabiceeae (Rubiaceae); phylogenetic relationships based on $r b c \mathrm{~L}$ data. Plant Systematics and Evolution 211: 71-92.

Bridson, D. M. 1985. The reinstatement of Psydrax (Rubiaceae, subfam. Cinchonoideae tribe Vanguerieae) and a revision of the African species. - Kew Bulletin 40: 687-725.

Bridson, D. M. 1986. The reinstatement of the African genus Keetia (Rubiaceae, subfam. Cinchonoideae tribe Vanguerieae). - Kew Bulletin 41: 965-994.

Bridson, D. M. 1987a. Studies in African Rubiaceae - Vanguerieae: a new circumscription of Pyrostria and a new subgenus, Canthium subgen. Bullockia. - Kew Bulletin 42: 611-639.

Bridson, D. M. 1987b. The recognition and recircumscription of the African genus Multidentia (Rubiaceae - Vanguerieae). - Kew Bulletin 42: 641-654.

Bridson, D. M. 1992. The genus Canthium (Rubiaceae - Vanguerieae) in tropical Africa. - Kew Bulletin 47: 353-401.

Bullock, A. A. 1932. Canthium in British East Africa. - Bulletin of the Miscellanous Information of the Royal Botanic Gardens, Kew 8: 353-389.

De Block, P. \& Robbrecht, E. 1998. Pollen morphology of the Pavetteae (Rubiaceae, Ixoroideae) and its taxonomic significance. - Grana 37: 260-275.

Erdtman, G. 1952. Pollen morphology and plant taxonomy. Angiosperms. - Almqvist \& Wiksell, Stockholm.

Erdtman, G. 1971. Pollen morphology and plant taxonomy. Angiosperms. Corrected reprint of 1952 edition. - Hafner Publ. Co., New York.

Havard, A. \& Verdcourt, B. 1987. A pollen survey of Tapiphyllum (Rubiaceae - Vanguerieae). - Kew Bulletin 42: 605-609.

Huysmans, S. 1998. Palynology of the Cinchonoideae (Rubiaceae). Morphology and development of pollen and orbicules. - Ph.D. Thesis, Botanical Institute, K.U.Leuven.

Huysmans, S., Robbrecht, E. \& Smets, E. 1993. Endoaperture morphology in the Coptosapelteae (Rubiaceae - Cinchonoideae). - In: '11. Symposium Morphologie, Anatomie, Systematik', Kurzfassungen (ed. D. Fürnkranz \& H. Schantl), Beitr. 66. - University of Salzburg.

Huysmans, S., Robbrecht, E. \& Smets, E. 1994. Are the genera Hallea and Mitragyna (Rubiaceae - Coptosapelteae) pollen morphologically distinct? - Blumea 39: 321-340.

Huysmans, S., Robbrecht, E \& Smets, E 1998. A collapsed tribe revisited: pollen morphology of the Isertieae. - Review of Palaeobotany and Palynology 104: 85-113.

Igersheim, A. 1989. Beiträge zur Klärung der Gattungsabgrenzungsprobleme innerhalb der Rubiaceae - Vanguerieae. - Ph.D. Thesis, Botanical Institute, University of Vienna.

Jansen, S., Robbrecht, E. \& Smets, E. 1996. The systematic value of 
endexine ornamentation in some Psychotrieae pollen (Rubiaceae - Rubioideae). - Grana 35: 129-135.

Keddam-Malplanche, M. 1980. Le pollen et les stomates des Gardéniées (Rubiacées) du Gabon. Morphology et tendences évolutives. - Mémoires du Museum National d'Histoire Naturelle, ser. B, New Series 29: 1-109.

Lobreau-Callen, D. 1978. L'aperture composée des Rubiacées. Annales des Mines de Belgique 2: 167-173.

Malplanche, M. 1971. Etude palynologique de trois genres de Rubiacées-Gardéniées d'Afrique. - Adansonia 11: 343-355.

Persson, C. 1993. Pollen morphology of the Gardenieae - Gardeninae (Rubiaceae). - Nordic Journal of Botany 13: 561-582.

Punt, W., Blackmore, S., Nilson, S. \& Le Thomas, A. 1994. Glossary of pollen and spores terminology. - LPP Contrib. Ser. nr1. Laboratory of Palaeobotany and Palaeobotany Foundation, Utrecht.

Reitsma, T. 1969. Size modifications of recent pollen under treatments. - Review of Palaeobotany and Palynology 9: $175-202$.

Reitsma, T. 1970. Suggestions towards unification of descriptive terminology of angiosperm pollen grains. - Review of Palaeobotany and Palynology 10: 39-60.

Robbrecht, E. 1980. Bijdragen tot de classificatie van de Ixoroideae en tot de revisie van Tricalysia s.1. (Rubiaceae). Vol. 1. - Ph.D. Thesis, University of Gent.

Robbrecht, E. 1988. Tropical Woody Rubiaceae. - Opera Botanica Belgica 1 (Natl. Bot. Gard. Belg., Meise).

Robbrecht, E 1994 ('1993'). Supplement to the 1988 outline of the classification of the Rubiaceae. Index to genera. - Opera Botanica Belgica 6: 173-196.

Robbrecht, E., Huysmans, S \& Figueiredo, E 1996. The generic status of Oxyanthus gossweileri (Rubiaceae) from Angola. South African Journal of Botany 62: 17-22.

Robbrecht, E. \& Puff, C. 1986. A survey of the Gardenieae and related tribes (Rubiaceae). - Botanische Jahrbucher für Systematik 108: 63-137.

Robyns, W. 1928. Tentamen monographiae Vanguerieae generumque affinium. - Bulletin du Jardin Botanique de l'Etat, Bruxelles 11: 1-359.

Rova, J. 1999. Rubiaceae phylogeny based on rps16 sequence data. - Ph.D. Thesis, Botanical Institute, University of Göteborg.

Schumann, K. 1891. Rubiaceae. In: Die natürlichen Pflanzenfamilïen 4 (ed. A. Engler \& K. Prantl), pp. 1-156. - Engelmann Leipzig.

Stoffelen, P., Robbrecht, E. \& Smets, E. 1997. Pollen morphology of Coffea and Psilanthus (Rubiaceae - Coffeeae), mainly from Africa. - Grana 36: 313-327.

Tilney, P. M. \& van Wyk, A. E. 1997. Pollen morphology of Canthium, Keetia and Psydrax (Rubiaceae: Vanguerieae) in southern Africa. - Grana 36: 249-260.

Tilney, P. M., van Wyk, A. E. \& Kok, P. D. F. 1988. The taxonomic significance of anatomical characters of the stem in the southern African species of Canthium s.l. (Rubiaceae). South African Journal of Botany 54: 585-595.

Van Campo, M. 1978. La face interne de l'exine. - Review of Palaeobotany and Palynology 26: 301-311.

Verdcourt, B. 1958. Remarks on the classification of the Rubiaceae. - Bulletin van de Rijksplantentuin (Brussel) 28: 209-281.

Verdcourt, B. 1987. Notes on African Rubiaceae - Vanguerieae. Kew Bulletin 42: $123-199$.

Walker, J. W. \& Doyle, J. A. 1975. The basis of angiosperm phylogeny: palynology. - Annals of the Missouri Botanical Garden 62: 664-723. 